\title{
CONSTRUCTION 4.0: A SURVEY OF RESEARCH TRENDS
}

SUBMITTED: December 2019

REVISED: August 2020

PUBLISHED: September 2020

EDITOR: Esther Obonyo

DOI: $10.36680 /$ j.itcon.2020.024

Nathalie Perrier, Research Associate,

Department of Mathematics and Industrial Engineering, Polytechnique Montréal, Canada. nathalie.perrier@polymtl.ca

Aristide Bled, M.Sc.A.,

Department of Mathematics and Industrial Engineering, Polytechnique Montréal, Canada. aristide.bled@polymtl.ca

Mario Bourgault, Full Professor,

Department of Mathematics and Industrial Engineering, Polytechnique Montréal, Canada. mario.bourgault@polymtl.ca

Nolwenn Cousin, M.Sc.A.,

Department of Mathematics and Industrial Engineering, Polytechnique Montréal, Canada. nolwenn.cousin@polymtl.ca

Christophe Danjou, Assistant Professor

Department of Mathematics and Industrial Engineering, Polytechnique Montréal, Canada. christophe.danjou@polymtl.ca

Robert Pellerin, Full Professor,

Department of Mathematics and Industrial Engineering, Polytechnique Montréal, Canada. robert.pellerin@polymtl.ca

Thibaut Roland, M.Sc.A.,

Department of Mathematics and Industrial Engineering, Polytechnique Montréal, Canada.

thibaut.roland@polymtl.ca

SUMMARY: The fourth industrial revolution, called Industry 4.0, is transforming decision-making through the increasing use of information and digitization technologies. While Industry 4.0 is expanding rapidly in manufacturing industries, its induced transformations are gradually affecting other sectors, including the construction industry. In recent years, the use of 4.0 technologies in the construction industry, termed as 'Construction 4.0', has increased, mostly due to the immense potential of Industry 4.0 for improving the performance of construction projects and structuring their underlying management processes. This paper proposes a classification of existing literature on applications of Construction 4.0 technologies to allow for a better analysis of trends and gaps in the research. A total of nearly 200 research papers between 2009 and 2020 were reviewed and analyzed. Overall, the analysis shows that research on Construction 4.0 is closely aligned with the construction phase. Also, the most researched topics seem to be related to the management processes of quality, risk, and health and safety.

KEYWORDS: Construction industry; Industry 4.0; Construction 4.0; Digital technologies

REFERENCE: Nathalie Perrier, Aristide Bled, Mario Bourgault, Nolwenn Cousin, Christophe Danjou, Robert Pellerin, Thibaut Roland (2020). Construction 4.0: a survey of research trends. Journal of Information Technology in Construction (ITcon), Vol. 25, pg. 416-437, DOI: 10.36680/j.itcon.2020.024

COPYRIGHT: ( $) 2020$ The author(s). This is an open access article distributed under the terms of the Creative Commons Attribution 4.0 International (https://creativecommons.org/licenses/by/4.0/), which permits unrestricted use, distribution, and reproduction in any medium, provided the original work is properly cited. 


\section{INTRODUCTION}

In the last decade, the growing use of a wide range of technologies has enabled the digitization, automation, and integration of the construction processes at all phases of the construction value chain (Oesterreich and Teuteberg, 2016). This tendency can be referred to as 'Construction 4.0' (the German term for Construction 4.0 can be traced back to 2016 in the paper by Oesterreich and Teuteberg). In fact, the fourth industrial revolution, also known as Industry 4.0, has been impacting the construction sector in a concrete manner since 2009. In brief, the development and adoption of Building Information Modeling (BIM) tools have brought planning functions closer to the actual sequence of work execution by allowing the visualization of the projected execution over time of a digital model (4D planning) and the expected costs (5D planning) (Wang et al., 2014).

Other 4.0 technologies are characterized by connected systems of sensors, intelligent machines, mobile devices, and new software applications (Gerbert et al., 2016). For example, advanced digital technologies now include the use of drones to survey and inspect construction sites (Hilfert and König, 2016). New additive manufacturing methods, such as 3D printing, are applicable to large-scale building components (Gerbert et al., 2016). Also, 3D scanners can be used to create digital models of complex buildings, while Global Positioning System (GPS) and Radio Frequency IDentification (RFID) can be used to track materials, equipment, and workers (Gerbert et al., 2016).

However, in practice, Construction 4.0 does not correspond solely to the use of new or existing technologies in the field of construction. The concept of Construction 4.0 also implies a comprehensive and profound transformation of the project management processes of construction firms through the use and exploitation of data collected in real time using new or existing technologies for decision-making purposes (Dallasega et al., 2018). These processes need to be studied to favour the valorisation of relevant information captured using 4.0 technologies at all phases of a project's life cycle with the aim of exploiting such information in real time and afterwards. The main uses of these 4.0 technologies and the applications that can be associated with them also need to be studied in order to bring out all the benefits they can generate in the construction industry.

In fact, Industry 4.0 is still far from being used to its full potential in the construction sector. When compared to other industries, such as business services, manufacturing, finance, transport and utilities, the construction industry still lags in terms of investment in and adoption of 4.0 technologies (Underwood and Isikdag, 2011). The limited progress in the adoption and implementation of new technologies in the construction sector highlights not only potential barriers in applying Industry 4.0 technologies, such as economic implementation cost, acceptance of technology, higher requirement for construction equipment and process, lack of knowledge, and individual hesitance (Aripin et al. , 2019), but also the considerable difficulties of construction projects facing project managers (Dallasega, 2018). These projects are especially complex because of the high numbers of interrelated processes, sub-processes and participating actors at different stages of the project's life cycle and in different locations, and subject to a great level of uncertainty especially during the early phases. Construction projects also require high degrees of customization. They thus are incredibly diverse.

Given the importance of good management of the underlying processes in construction projects, any improvement in access to information (e.g., gains in automation and richer building information) can lead to more effective decision-making that could facilitate these processes (Isikdag et al., 2012), thus leading to cost savings, time saving, and improving quality and safety (Aripin et al., 2019) . In this context, several questions need to be addressed, including:

- Which phases of the construction project's life cycle are currently being facilitated, transformed or even renewed using construction 4.0 technologies?

- Which project management processes are currently being transformed using 4.0 technologies in the construction industry?

- What are the main actions of these technologies and what are their most common applications?

The objective of this paper is to provide a comprehensive classification of the currently researched and applied 4.0-related technologies in the construction industry. This classification is based on the elements of the research questions. More specifically, the Construction 4.0 technologies identified in the literature are classified according to the usual phases of a construction project, the typical processes for managing a construction project, and the applications most often associated with these technologies. The remainder of the paper is organized as follows. Section 2 first describes the characteristics of existing analytical frameworks in Construction 4.0. 
Section 3 addresses the methodology that resulted in a classification of relevant research on Construction 4.0. Section 4 presents key technologies and concepts in the context of Construction 4.0, while several applications of these technologies are studied in Section 5. A classification of relevant research on applications of Construction 4.0 technologies is provided in Section 6, followed by a discussion of research trends in Section 7. Conclusions and direction for future research are presented in the last section.

\section{REVIEW OF ANALYTICAL FRAMEWORKS IN THE CONTEXT OF CONSTRUCTION 4.0}

In the past decade, there have been many important developments in the construction sector to improve operations and to achieve significant savings in project time and cost management (Son et al., 2010). These developments mainly include the digitization of the whole engineering and construction value chain as well as that of the operation and maintenance phase (Son et al., 2010). Efforts have also been deployed to classify key 4.0 technologies for construction into several main groups. For example, Oesterreich and Teuteberg (2016) identified several key technologies and concepts in the context of Industry 4.0 for construction and grouped them into three main clusters: smart factory, simulation and modeling, and digitization and virtualisation. According to Oesterreich and Teuteberg (2016), central concepts in the first cluster include cyber-physical systems/embedded systems, automation, RFID, the Internet of Things and Services (IoT and IoS), additive manufacturing, modularisation (also known as prefabrication), robotics, product-life cycle-management, and human-computer interaction. The second cluster deals with simulation and modelling tools, another core part of Industry 4.0. Among them, the field of BIM can be considered as one of the central technologies to support the main idea of Industry 4.0, whereas the fields of augmented, virtual, and mixed reality (AR, VR, MR, respectively) are still at the formative stage, as applications for the use on construction projects are still being developed. The third cluster contains technologies relating to digitization and virtualisation. These technologies include cloud computing, big data, mobile computing, and social media.

Dallasega et al. (2018) identified six major research topics concerning Industry 4.0 concepts that are relevant to Construction Supply Chains (CSC): digitization (management information system, real-time Supply Chain Management (SCM), intelligent transportation systems, connected vehicle systems), cloud computing (Web services technology, mobile Internet-based construction SCM, collaboration technology), BIM (information integration and sharing, monitoring CSC, supply chain performance improvement, decision support, BIM supporting construction SCM), 3D printing, tracking and localization (Geographic Information Systems, GIS, and RFID), and e-supply chain management (Web portal, e-business, extranet). The concepts and technologies of these clusters were grouped into a comprehensive framework to rate their utility to construction supply chains.

In an effort to give an overview of the main research work carried out on digital technology that applies to improving the operation and maintenance stage of the building life cycle, Wong et al. (2018a) categorised the various types of digital technologies surveyed into four major groups: BIM, GIS, IoT (i.e. RFID and sensor network technologies), and reality capture technology (i.e. point cloud, photogrammetry, 3D laser scanning). Similarly, Qin et al. (2016) presented a framework for Industry 4.0 and manufacturing that combines three intelligence level technologies acting on three automation of production systems. The resulting nine types of manufacturing applications indicate previous, recent, and future industrial implementations. These nine applications go from low-intelligence and simple automation to high-intelligence and complicated automation (e.g., the implementation of Smart Factory). Although this implementation of Industry 4.0 deals with the manufacturing sector, the framework can be adapted and applied to the construction sector to help reach the goals of Industry 4.0.

In other works, technologies have been classified according to the phases of a construction project's life cycle in which they are mostly used. For example, Son et al. (2010) showed that the majority of the work published in the proceedings of the International Symposium on Automation and Robotics in Construction during the period 1990-2008 (except 1998) focuses on technologies that are most closely aligned with the construction phase. These technologies can be classified into two main categories: Construction Robotics and Intelligent Job-Site Management. In the first category, more than half of the research focuses on control systems, automated systems, earth-working equipment, sensor systems, heavy lifting equipment, or path planning systems. Similarly, the topics of research within the Intelligent Job-Site Management category focus on construction management systems, sensors and sensing, simulation tools, knowledge management, or prefabrication. Gerbert et al. (2016) 
highlighted the main digital technologies that can be applied to all phases of the engineering and construction value chain. Also, De Groote and Lefever (2016) provided a high-level overview of the traditional construction sector from a life cycle perspective. This overview shows which conventional actors are involved at the different stages such as product manufacturing, design, construction, operation, renovation and demolition.

Today, BIM can be considered as one of the central technologies for the digitization of the construction manufacturing environment (Dallasega et al., 2018). The work carried out in this field is therefore extensive. One notable example of the importance of BIM is the study undertaken by Megahed (2015) on the evolution of BIM throughout the building's life cycle. Based on a 3D model with the fourth $(3 \mathrm{D}+$ time element), fifth $(3 \mathrm{D}+$ time + cost element), sixth (3D + analysis element), and even seventh $(3 \mathrm{D}+$ facility management applications) dimensions, the author pointed out that BIM can help users share project information throughout the entire construction life cycle, from the design team to the construction team and to the building owner/operator, by allowing each stakeholder to add to and refer back to all information they acquired during their period of use of the BIM model. Several other studies have been carried out on the use of BIM in the field of construction. For example, substantive work has been done on cloud-BIM (Wong et al., 2018b) and linking BIM to construction lifecycle phases (Chowdhury et al., 2019).

More recently, Edirisinghe (2019) provided a classification of the existing research related to the development of sensor technologies for construction sites based on the different stages of the technology development process, i.e., from basic research principles, analytic studies, laboratory studies, prototyping, and field tests to product commercialisation and deployment of industrial system. The application areas reviewed, which mainly focus on the construction phase, concern augmented reality, building information model-based visualisation, labour tracking, supply chain tracking, safety management, mobile equipment tracking, and schedule and progress monitoring. Also, Tetik et al. (2019) developed a technology-based operations management practice aiming to improve performance over the building's lifecycle through a detailed and complete digital design model, resulting in increased reusability, project-specific differentiation, and automation of designs and processes across projects. Finally, Hossain and Nadeem (2019) proposed a framework to incorporate new technologies within construction projects. The framework incorporates, among others, current technological advancement related to construction industry, legislative requirements, barriers, and enterprise transformation requirements.

In sum, most of previous developments in Construction 4.0 either focused on the grouping of technologies from a project's life cycle perspective or on BIM applications. In this paper, we intend to provide a multi-layered mapping of Industry 4.0-related technologies and their applications in the construction sector. More precisely, the reviewed studies are classified according to three layers: 1) the main actions of 4.0 technologies; 2) the different phases of a construction project's life cycle, which include the pre-construction phase (design and engineering), the construction phase, and the post-construction phase (operation and maintenance and renovation); and 3) the project management processes that can be improved using these technologies in the construction industry. The resulting classification provides valuable insights regarding the use of different technologies to meet different needs in the construction industry. This classification can provide guidelines for construction practitioners who are interested in implementing technology-driven construction management. Based on the gaps identified, further research can also facilitate the adoption of 4.0 technologies in the construction industry.

\section{ARTICLE SELECTION METHODOLOGY}

This study involved a document search on Construction 4.0 using the Scopus database. Scopus covers a wide range of journals, allowing multidisciplinary exploration and identification of indexed documents and citations in the studied fields. The use of Scopus for literature searching is common in the engineering and technology research fields. The search terms consisted of combinations of the following keywords: 'construction industry' or 'building industry' or 'innovation construction' or 'innovation building' or 'construction site' or 'building system' or 'construction sector' or 'BIM' or 'building information model', and '4.0' or 'digital'. The importance of BIM in the emergence of Industry 4.0 in the construction sector led to the inclusion of this keystone in the search terms. This search generated more than 2000 documents. Comparing different types of 4.0 technologies, we found that BIM is by far the most widely discussed (939 times) in the literature. We then retained the research papers explicitly presenting progress on the use of Industry 4.0 technologies in the construction industry during the last decade (between 2009-2020). As a result, a total of 198 publications were identified using this 
approach. As shown in Figure 1, conference papers and journal articles constitute the largest part of the 198 reviewed documents.

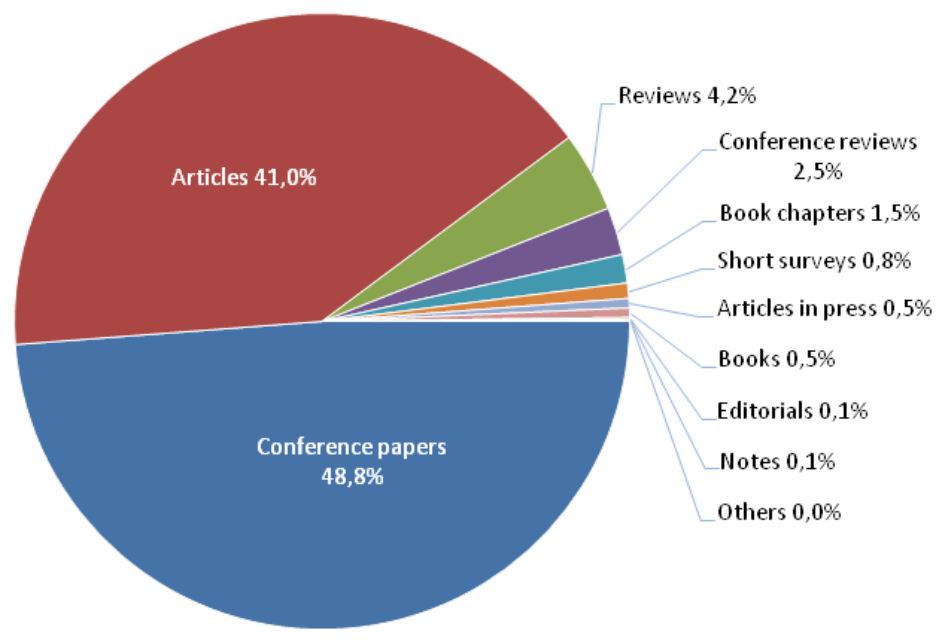

FIG. 1. Documents by type.

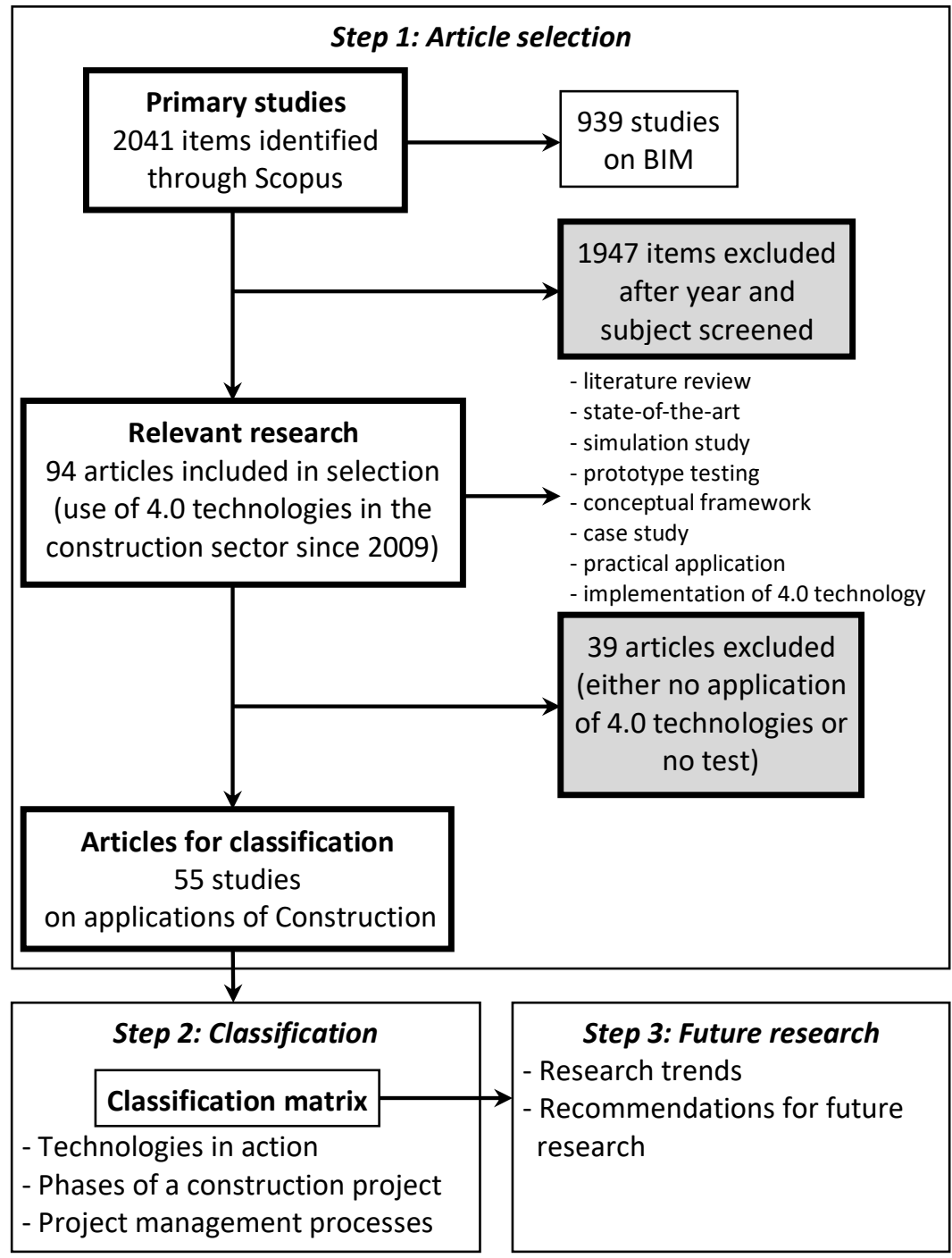

FIG. 2. Representation of the methodology. 
Of the 198 publications, the most relevant on the topic of this paper were then selected for a total of 94 publications. The selected publications concern one or the other of the following categories: literature review and state-of-the-art, simulation study, testing a tool or prototype, case study and practical application, and implementation of a 4.0 technology. Among these publications, only those explicitly dealing with applications of 4.0 technologies in the construction industry were withheld. This constraint resulted in a collection of 70 documents that focused on the applications of Construction 4.0 technologies. We also note that we are interested in applications of Industry 4.0 technologies that have been either tested in a laboratory, or in real situations, resulting in a total of 55 documents. Figure 2 presents a graphical summary of the methodology that resulted in the classification matrix presented in Section 6 and the research trends discussed in Section 7.

\section{TECHNOLOGIES IN THE CONSTRUCTION SECTOR}

Unlike the manufacturing sector, which has seen the emergence of many integrated business management software, there is no single and integrated solution that brings together 4.0 technologies in the construction industry (Danjou et al., 2020). Indeed, while the integrated model of BIM has been a central driving force in the emergence of Industry 4.0 in the construction field, current trends include the emergence of various nonintegrated technological solutions (Danjou et al., 2020). As illustrated in Figure 3, which is based on the 94 publications selected in the literature search (see Section 3), these technologies are related to data science, digital fabrication, prefabrication, BIM, artificial intelligence (AI), modelling systems (AR/VR, nD modeling) or technologies related to monitoring such as GIS (laser scanning, drones, Unmanned Aerial Vehicles (UAVs), photogrammetry, GPS) and material tracking (RFID tags). The numbers in brackets associated with the technology groups in Figure 3 correspond to the number of times a technology in a group is discussed in the 94 articles included in selection. It should be noted that more than one technology can be discussed in the same article, therefore the total is greater than 94 papers.

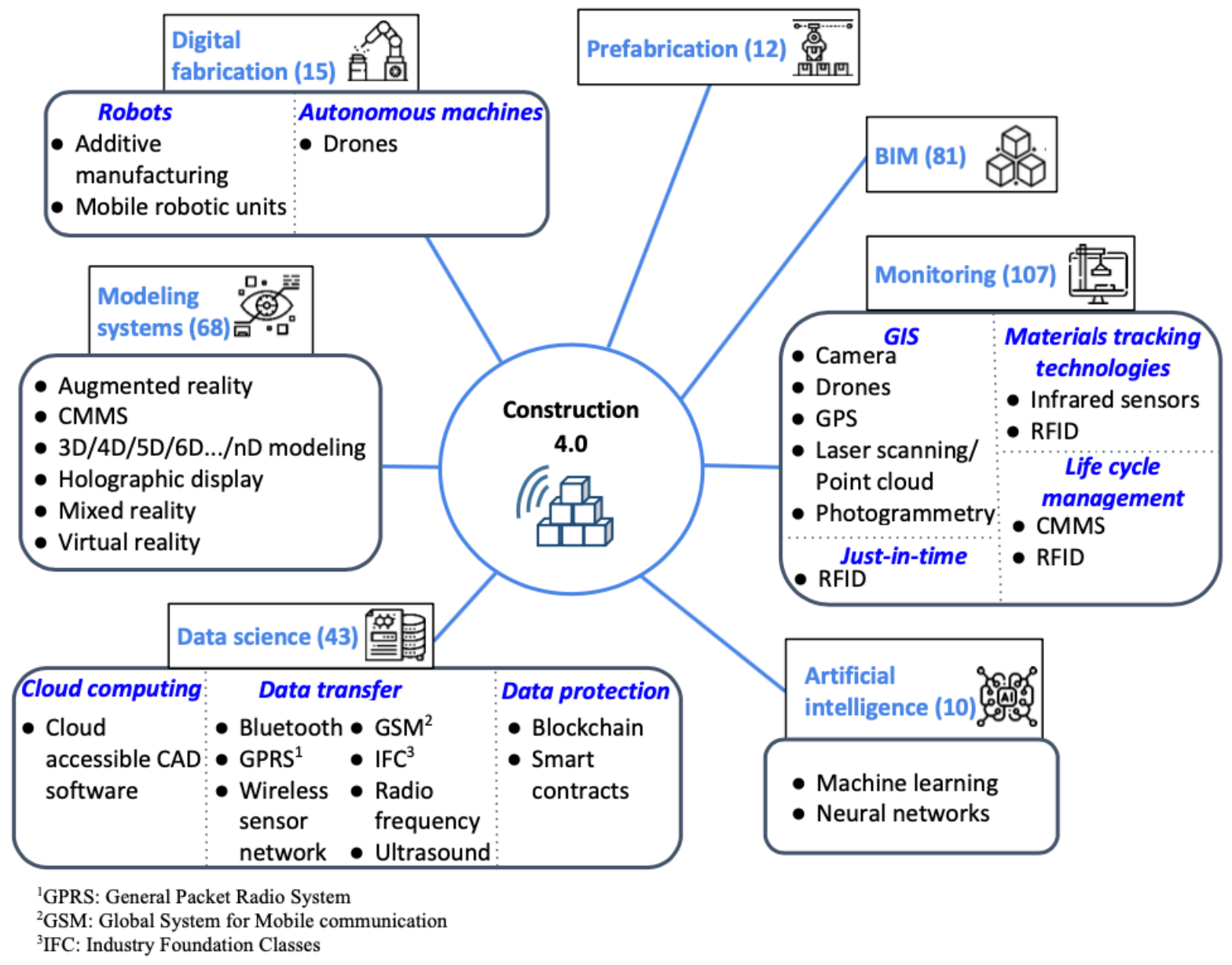

FIG. 3. Seven technology groups and their supporting technologies. 
As mentioned by several authors (Gerbert et al., 2016; Oesterreich and Teuteberg, 2016; Steel et al., 2010), BIM is considered as the key feature of Construction 4.0. As the successor to traditional CAD (Computer-Aided Design), BIM now serves all stakeholders along the project's life cycle, using virtual modeling and information to simulate any aspect of the project's life cycle (Tezel and Aziz, 2017). In recent years, the use of BIM has increased mostly due to the potential of the methodology for improving construction project performance and efficiency, controlling effectively project implementation goals of quality, cost and time, supporting real-time decision-making, and finding potential safety hazards ahead of time (Santos et al., 2017; Wang, 2013). Integrated with other emerging technologies, BIM also enables further data manipulation (Tezel and Aziz, 2017).

As shown in Figure 3, monitoring technologies are discussed 107 times in the relevant research; this indicates that monitoring technologies are most often the primary focus in the research. This is somewhat foreseeable, as monitoring is a prerequisite for the effective and efficient cost management of labour, plant and equipment, and materials (Pärn and Edwards, 2017). Traditionally, tracking progress on a construction site has been achieved through video footage. Recently, laser scanning technology (such as Light Detection And Ranging, LiDAR) has been utilised for tracking structural work progress and quality (Dallasega et al., 2018), while RFID tags are used to track the location and movement of machines and workers to capture their productivity and safety performance (Pärn and Edwards, 2017).

Among the other associated technologies and concepts related to monitoring are well-known manufacturing concepts like life cycle management or just-in-time production that can be applied through information and communication technologies like RFID and CMMS (Computerized Maintenance Management System) (Dallasega et al., 2018; Oesterreich and Teuteberg, 2016).

Another important field explored by researchers in the monitoring category is the use of GIS. For example, the integration of GIS with multiple resources, such as BIM and sensors, facilitate fusion of information, benefiting many fields ranging from emergency response, urban monitoring to smart building (Isikdag, 2015).

Modeling systems and data science are also major components of Construction 4.0. Modeling systems include $\mathrm{AR} / \mathrm{VR} / \mathrm{MR}$ to enable a digitized construction environment, as well as $\mathrm{nD}$ (n-dimensional) modeling, an extension of the BIM model that incorporates multiple aspects of design information required at each stage of the project's life cycle (Dallasega et al., 2018). Data science can support project managers in more effective decision-making through increased access to information (Dallasega et al., 2018). Typical base technologies and concepts of data science are cloud computing, data transfer and data protection (Woodhead et al., 2018). The latter includes blockchain, which has many potential applications in construction enabling traceability that can be, in some cases, facilitated by smart contracts (Woodhead et al., 2018).

\section{CONSTRUCTION 4.0 TECHNOLOGIES AND THEIR APPLICATIONS}

Many of the technologies presented in the previous section can be applied to all phases of a construction project's life cycle. In this section, we study several examples of these 4.0 technologies applied to real cases in the construction sector. In order to make a classification of the different applications of Construction 4.0 technologies, the applications identified in the 55 selected documents (see Figure 2) can be categorized in ten broad actions: automate, communicate, distribute, locate, model, optimize, reconstruct, simulate, standardize, and visualize. These actions were identified based on the descriptions of identified applications in the selected documents. Table 1 presents the ten actions associated with applied Construction 4.0 technologies. The table shows that the same technology can have several different actions. In what follows, each of these actions is briefly discussed.

Automate. This action can be defined as total or partial execution of technical tasks without human intervention. For example, robotic machines can turn data into physical action, autonomously and safely (Gerbert et al., 2016). This enables automated and unmanned tasks at construction sites (Gerbert et al., 2016). Drones and laser scans are used to measure production volumes several times a day in order to solve productivity problems for management (Woodhead et al., 2018). Real-time data analysis has been made possible through machine learning (Whyte and Hartmann, 2017). A higher level of automation in sustainable building design is also needed, for example through the application of BIM and AI (Lim et al., 2018). Also, robotic automation of the steel beam assembly and bricklaying robots are now used on construction sites to replace human workers (Oesterreich and Teuteberg, 2016). 
Table 1. Actions associated with applied Construction 4.0 technologies.

\begin{tabular}{|c|c|}
\hline Actions & Technologies \\
\hline \multirow{5}{*}{ Automate } & Crabots \\
\hline & 3D printing \\
\hline & Mobile robotic units on site \\
\hline & Neural networks/Artificial intelligence (AI) \\
\hline & Unmanned aerial vehicle (UAV)/Drone \\
\hline \multirow[t]{3}{*}{ Communicate } & Mixed reality/Virtual reality (MR/VR) \\
\hline & Radio frequency identification (RFID) \\
\hline & Wireless sensor network (WSN) \\
\hline \multirow[t]{2}{*}{ Distribute } & n-dimensional (nD) modeling \\
\hline & RFID \\
\hline \multirow[t]{14}{*}{ Locate } & Barcode \\
\hline & Bluetooth/RFID \\
\hline & Camera \\
\hline & Geographic information system (GIS) \\
\hline & Global system for mobile communication (GSM) \\
\hline & Third/Fourth generation $(3 \mathrm{G} / 4 \mathrm{G})$ \\
\hline & Wireless fidelity (Wi-Fi) \\
\hline & Global positioning system (GPS) \\
\hline & Laser scanning/Laser Detection and Ranging (LaDAR)/LIght Detection and RAnging (LIDAR) \\
\hline & $\mathrm{nD}$ modeling \\
\hline & RFID \\
\hline & Sensors \\
\hline & UAV/Drone \\
\hline & VR \\
\hline Model & $\mathrm{nD}$ modeling \\
\hline \multirow{6}{*}{ Optimize } & Augmented reality \\
\hline & Bluetooth \\
\hline & Mobile devices \\
\hline & Neural networks/AI \\
\hline & Parametric design (PD) \\
\hline & RFID \\
\hline \multirow[t]{6}{*}{ Reconstruct } & Camera \\
\hline & GIS \\
\hline & Laser scanning/LaDAR/LiDAR \\
\hline & Point cloud/3D scanner \\
\hline & Photogrammetry/Stereo-photogrammetry \\
\hline & UAV/Drone \\
\hline \multirow[t]{8}{*}{ Simulate } & Blockchain \\
\hline & Digital twin \\
\hline & GIS \\
\hline & Industry foundation classes (IFC) \\
\hline & Machine learning \\
\hline & Neural networks/AI \\
\hline & $\mathrm{nD}$ modeling \\
\hline & VR \\
\hline \multirow[t]{3}{*}{ Standardize } & IFC \\
\hline & Parametric design (PD) \\
\hline & Prefabrication \\
\hline \multirow[t]{5}{*}{ Visualize } & Augmented reality (AR) \\
\hline & Smartphone camera \\
\hline & Holographic display \\
\hline & $\mathrm{nD}$ modeling \\
\hline & VR \\
\hline
\end{tabular}


Communicate. Several technologies for transmitting data, information, or knowledge to a human are available. Mobile communication technology applied with Internet technology to the construction sector is commonly used to improve real-time information sharing and communication (Wong et al., 2018a). In that sense, RFID and wireless sensor network technologies are considered two of the fastest growing information and communication technologies (Wong et al., 2018a). In addition, technologies like VR/MR combined with mobile devices, can increase customers' understanding of the final product early in the design phase to avoid wasteful changes during project execution (Dallasega et al., 2018). Other construction information technology (IT) applications include, for example, IT based visual management (Tezel and Aziz, 2017), IT solutions to the management of remote construction sites (Sidawi, 2012), and integration of IT-tools in the organizing and communication processes in construction projects (Gustavsson et al., 2012).

Distribute. This action focuses on placing in space human or material as a function of time. For example, using embedded sensors like RFID, automatic tracking of equipment and materials can reduce material costs (Dallasega et al., 2018). RFID is also being used for access control to avoid site access by unauthorized personnel and to track in real time the number and identities of workers on construction sites (Oesterreich and Teuteberg, 2016).

Locate. A large number of technologies are used for tracking the positioning of human and material in space and time. In fact, mobile solutions in construction engineering projects have been greatly improved during the last decade (Laine and Ikonen, 2011). The processing speeds of smart phones along with the capacity and availability of modern mobile networks now enable new possibilities for more effective information management (Laine and Ikonen, 2011). Smartphone cameras can now be used to scan barcode and digital RFID tags that are permanently attached to specific building elements (Laine and Ikonen, 2011). Modern mobile networks (3G, 4G, Wi-Fi) capable of utilizing broadband bandwidths have also become common (Laine and Ikonen, 2011). RFID is used to receive signal strength as a proxy for distances to locate people and materials inside buildings using Ultra High Frequency (UHF) radio waves (Woodhead et al., 2018). Location of workers, assets and equipment can be tracked in real time by using the RFID technology and GPS for safety management, facilities management, processes management, and activity base progress measurement purposes (Tezel and Aziz, 2017). LiDAR, Laser Detection And Ranging (LaDAR) and 3D laser scanners are also very effective in locating topographic features, defining feature geometries and creating 3D surfaces (Tezel and Aziz, 2017).

Model. This specific action starts from a proposed structure and translates it into a digital model. A typical example is the process recognised as $\mathrm{nD}$ modeling, which integrates multiple dimensions of information such as time and cost into a digital building model (e.g., BIM) starting from the initial design to the final construction stage.

Optimize. This action is focussing on making a system work optimally. For example, neural networks are used to optimize crane location on site (Irizarry and Karan, 2012). Combined with statistical techniques, neural networks are also used to optimize the construction process and improve the construction efficiency (Zhao et al., 2017).

Reconstruct. This action translates an existing physical system into a digital model. In this category, several technologies can support the information used for conservation and in heritage science projects. For example, combining digital photogrammetry with laser scanning allows the capture of high-resolution photographs of materials' textures and as a consequence, information of material degradation (Pocobelli et al., 2018). 3D information pertaining to the built heritage can also be collected and processed using cloud-based photogrammetry (Scott et al., 2013). Sensors such as 3D laser scanners, Red-Green-Blue (RGB) camera and thermal camera can be merged to obtain complete and accurate 3D thermal point cloud models of interiors of buildings (Adán et al., 2017). Finally, 3D visualization can provide important support for urban planning, construction and management (Yeniceli and Ozcelik, 2015).

Simulate. This action aims at representing the behavior of a given process. Using the $\mathrm{nD}$ modeling approach, the construction industry has started to focus on making pre-construction simulations (Pocobelli et al., 2018). Simulation enhanced through holographic technology, for instance, and rapid prototyping with 3D-printed models speeds up design iterations and improves visualization. Simulation and visualization also help construction planners to identify potential accessibility problems and unsafe situations on construction sites and avoid them early in the design and planning stages (Lin et al., 2013). For example, transportation processes can 
be simulated in an interactive, realistic virtual environment to identify potential safety and accessibility problems of the site layout plan.

Standardize. In the construction industry, standardization can be viewed as a key enabler and facilitator of data level interoperability (Isikdag et al., 2012; Steel et al., 2010). As a result, this area has been a focus of the BIM standard, such as Industry Foundation Classes (IFC), which can be interpreted as a means of exchanging information (Hjelseth, 2017). Over the years, a large number of BIM standards and guidelines have been developed for different purposes. These guidelines have been updated due to various experiences and to keep up with the users' development or maturity, as well as the increasing complexity of construction projects (Hjelseth, 2017).

Visualize. Several technologies have been proposed in the literature and used to make a digital model visual. For example, smart phones can be used to identify elements on construction sites to request and view imagery from a BIM software (Laine and Ikonen, 2011). Automatic texture acquisition is also made possible through visual modeling and VR (Oreni et al., 2012).

\section{CLASSIFICATION OF APPLIED RESEARCH ON CONSTRUCTION 4.0}

The objective of this literature review is to present an overview of the researched and applied Industry 4.0related technologies in the construction industry. To this end, the 55 relevant documents on applications of Construction 4.0 technologies (see Figure 2) are classified according to three suitable targets:

(i) Ten actions associated with applied 4.0 technologies in the construction sector: automate, communicate, distribute, locate, model, optimize, reconstruct, simulate, standardize, and visualize. These actions have been discussed in Section 5.

(ii) Four phases of a construction project's life cycle. These phases include the initial design and engineering, followed by the actual construction, the operation and maintenance of the built environment over the course of its useful life, and the renovation. It is common practice in the construction industry to assess the effectiveness of a technology in terms of the values added in the different phases of a construction project (Burgess et al., 2018; Chowdhury et al., 2019; De Groote and Lefever (2016); Megahed, 2015; Son et al., 2010). In this paper, research on Construction 4.0 has thus been classified along those same phases.

(iii) Nine project management processes: project communications management, project cost management, project health and safety management project human resources management, project procurement management, project quality management, project risk management, project scope, project time management. These processes are based on the PMBOK (Project Management Body of Knowledge) knowledge domains (Project Management Institute, 2013).

Table in the Appendix A presents the resulting classification matrix of applied Construction 4.0 technologies based on these three targets. These technologies are reviewed in the next four sections according to the four phases of a construction project's life cycle. In the table, we note that Construction 4.0 technologies cannot be aligned (N/A) with the scope management process during the construction and renovation phases. The blank cells, however, indicate gaps and new opportunities for future research.

\subsection{Design and Engineering}

Studies related to the design and engineering phase cover almost all project management processes, but especially focus on simulate tools. These tools, which are used in smart contracts, cost estimation, testing of design solutions, safety training and avoidance of crane collisions, cover a wide range of technologies, including blockchain (Woodhead et al., 2018), nD modeling/drone/point cloud (Lee et al., 2016), WSN/advanced sensors (Petri et al., 2017), UAV/laser scanning (Getuli et al., 2017; Moum, 2010), VR (Oesterreich and Teuteberg, 2016) and GIS (Araszkiewicz, 2017; Irizarry and Karan, 2012).

The remaining research associated with the design and engineering phase includes modeling and visualization tools, which serve as a comprehensive aid in the design process. These tools use $\mathrm{nD}$ modeling and VR (Abolghasemzadeh, 2013; Oreni et al., 2012) and deal with issues such as digital 3D models (Oreni et al., 2012), $3 \mathrm{D}$ visualization of building information (Shuo, 2013) and safety management (Abolghasemzadeh, 2013). UAV and laser scanning are also used for testing and verification of dynamic design solutions (Getuli et al., 2017; 
Moum, 2010), while the application of BIM and genetic algorithms has been explored to support decisionmaking and optimization for sustainable building design (Lim et al., 2018).

\subsection{Construction}

Research related to the construction phase has concentrated on how to achieve greater productivity and safety on construction sites. As a result, technologies in the construction phase have been mainly developed to deal with applications such as safety inspection (Oesterreich and Teuteberg, 2016; Tezel and Aziz, 2017), site monitoring (Dallasega et al., 2018), process efficiency improvement (Monizza et al., 2018), and measurement of production volume and calculation of productivity (Woodhead et al., 2018). The body of research on the application of mobile devices for real-time data collection (Dubas and Pasławski, 2017; Hu et al., 2018; Laine and Ikonen, 2011; Whyte and Hartmann, 2017) is growing rapidly, and numerous types of mobile devices and communication devices, such as global positioning systems (GPS) (Tezel and Aziz, 2017) and RFID devices (Dallasega et al., 2018; Ehrbar, 2016; Lin et al., 2013; Oesterreich and Teuteberg, 2016; Wang, 2013; Woodhead et al., 2018), are already in use on construction sites.

As observed in Appendix A, among all the technologies in the construction phase, Locate technologies are now widely used in various management processes of construction, including cost management, human resource management, risk management, procurement management and safety management. Locate technologies cover the latest construction technologies, such as drones, UAV, photogrammetry, GPS, RFID, Bluetooth, ultra sound, GIS, UHF, VR, WSN, nD modeling and advanced sensors. Research on heavy-lifting equipment, including cranes, which has focused on the avoidance of crane collisions, comprises technologies such as GIS in project risk management and neural networks in project safety management (Araszkiewicz, 2017; Irizarry and Karan, 2012). Also, research on monitoring technologies for the construction phase, which include drones and UAV, photogrammetry, GPS, camera/webcam, RFID and advanced sensors, deals with applications such as detection of human movements (Hilfert and König, 2016), location of workers, machines and waste (Castro-Lacouture et al., 2014; Pärn and Edwards, 2017; Tezel and Aziz, 2017), tracking of items (Dallasega et al., 2018) and mapping of objects on site (Laine and Ikonen, 2011), among others.

Interestingly, research on Automate tools in the construction phase has concentrated on the traditional triangle of quality, time, and cost management processes in order to improve productivity of construction tasks without human/manual involvement. These tools cover the latest automated technologies, including mobile robots on site for automated assembly and worker replacement (e.g., assembling bricks) (Oesterreich and Teuteberg, 2016). Robots enhance productivity, precision, and safety at the construction site, while 3D model guidance enables advanced levels of automation for construction equipment. For example, fully automated bulldozers are now guided by drones that map the area in real time and send a 3D model of the construction site to a computer which then instructs the unmanned machinery to plot its course.

The remaining of the most important research in the construction phase deals with issues such as standardization and optimization. Standardization essentially involves prefabrication, which is the typical means of reducing uncertainties related to the construction phase (Dallasega et al., 2018; Monizza et al., 2018). Optimize technologies, which have focused on heuristic methods for project planning, process efficiency improvement, flow optimization and optimization of crane location on site, include neural networks, parametric design and $\mathrm{nD}$ modeling (Irizarry and Karan, 2012; Monizza et al., 2018; Zhao et al., 2017).

\subsection{Operation and Maintenance}

In the construction industry, stakeholders have become increasingly aware of the importance of ensuring the durability of infrastructure (Son et al., 2010). Therefore, a fair amount of research has been devoted to facilitating the operation and maintenance of existing buildings. Most research in this category (see Appendix A) focuses on two topics: monitoring and emergency response.

Research on monitoring technologies, which employ various types of robots and sensors, deals with a wide range of applications, such as reshaping the building's functions and layout by redesigning modules, waste disposal (Oesterreich and Teuteberg, 2016), monitoring the condition of building elements (Hu et al., 2018; Wong et al., 2018a) and monitoring of structural deformations (Santos et al., 2017). 
Mobile devices, smartphones and GPS-enabled tools are geared toward a variety of applications related to safety and emergency response, such as location of occupants and fire sources, building fire safety reviews, guidance in case of evacuation and evacuation of occupants (Wong et al., 2018a).

\subsection{Renovation}

Very little work has been accomplished concerning the application of technologies related to the renovation phase. However, it should be noted that some renovation projects require the three previous phases (i.e., design and engineering, construction, and operation and maintenance) and therefore involve the use of the technologies covering these three phases.

During the renovation phase, the application of technologies is mostly used to enhance the quality management process by virtual migration of physical structures. For example, 3D laser scanning can be used to reconstruct an existing building by creating virtual 3D models (Pocobelli et al., 2018). That capability greatly benefits renovation projects by increasing accuracy of modeling and saving time relative to manual measurements (Gerbert et al., 2016). Also, waste that is generated during renovation and demolition of buildings, roads, bridges, and other infrastructure facilities has received increasing attention from researchers during the last decade. In this regard, the potential of BIM to facilitate demolition and renovation waste estimation seems to be a promising avenue for research (Cheng and Ma, 2013).

\section{DISCUSSION}

Table in Appendix A shows that existing 4.0 technologies are mainly used for Locate and Simulate actions. Furthermore, Table in Appendix A shows that the same technology can have several different applications. For example, drones can be used either for 3D modeling or for inspection and safety purposes (Oesterreich and Teuteberg, 2016; Tezel and Aziz, 2017). In fact, as shown in Table 2, the most commonly applied technologies are those that make it possible to locate. From the total number of 123 applications or technologies associated with any of the ten actions in the classification matrix, nearly one-third (35 of 123) are tools used to locate. These tools, which are applied to real cases at different phases of the project life cycle and in different project management processes, include smartphone cameras, barcodes, digital RFID tags, mobile networks (3G, 4G, Wi-Fi), GPS, LiDAR, LaDAR and 3D laser scanners.

In a similar way, Appendix A indicates that the same technology can be associated with different project management processes at different phases of a project's life cycle. This result relates to the versatility of a technology. Embedded sensors, for instance, can conduct real-time status monitoring activities during both construction and operations. Table 2 summarizes the number of times each of the ten actions associated with applied Construction 4.0 technologies appear in the classification matrix. As shown in Table 2, the most versatile technologies are those that allow either to locate or to simulate, each of these two actions appearing ten times in the matrix out of a total of 65 for all actions. These results are consistent with other studies stipulating that Locate concepts and technologies such as RFID are by far widely used in the construction industry (Dallasega et al., 2018).

Table 2. Frequency of appearance associated with actions in the classification matrix.

\begin{tabular}{|c|c|c|c|c|c|c|c|c|c|c|c|}
\hline Actions & 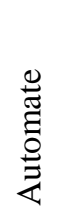 & 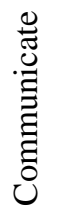 & 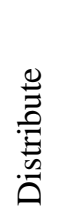 & 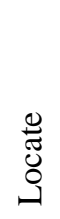 & $\begin{array}{l}\overline{0} \\
\bar{\Sigma}\end{array}$ & : & 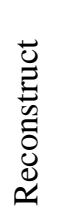 & 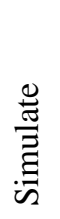 & 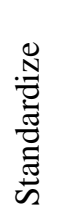 & 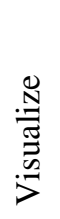 & $\stackrel{\widetilde{\pi}}{0}$ \\
\hline $\begin{array}{l}\text { Number of applications } \\
\text { associated with an action in the } \\
\text { classification matrix }\end{array}$ & 13 & 8 & 7 & 35 & 7 & 17 & 17 & 14 & 7 & 4 & 129 \\
\hline $\begin{array}{l}\text { Number of times an action } \\
\text { appears in the classification } \\
\text { matrix }\end{array}$ & 8 & 7 & 3 & 10 & 5 & 9 & 4 & 10 & 6 & 3 & 65 \\
\hline
\end{tabular}


In addition, existing 4.0 technologies mostly focus on the construction phase, as well as quality management, risk management and health and safety management processes. These results also confirm recent research findings in project planning, as well as other findings in the manufacturing sector. For example, even today, the emphasis in project planning research is mainly on activities carried out in the initial phases of a project, such as project scheduling (Pellerin and Perrier, 2018). Recent research in project scheduling has also produced a wide range of solution approaches with a strong interest in increased integration with risk management processes (Vanhoucke, 2018). Moreover, studies in the manufacturing sector have shown that the combination of data capture and data mining technologies for effective and decentralized real-time decision-making processes ranging from monitoring, control, real-time optimization, and complete autonomy (Moeuf et al., 2018) can generate operational gains mainly in traditional functions, such as scheduling, quality control and maintenance activity management (Bouslah et al., 2014, 2016a, 2016b, 2018; Hajji et al., 2012; Njike et al., 2012). Another category that has attracted the interest of several researchers in recent years is improving safety management in construction. In this area, fire safety, avoidance of crane collisions, and site safety planning are of major importance (Abolghasemzadeh, 2013; Araszkiewicz, 2017; Getuli et al., 2017; Irizarry and Karan, 2012; Wong et al., 2018a). Therefore, different methods for computer-aided modeling and simulation of egress scenarios, as well as various computer models and programs for egress analysis, including BIM integrated egress analysis (Abolghasemzadeh, 2013), have been developed.

However, a number of gaps can be identified from Appendix A, namely the analysis and comparison of 4.0 technologies to support the operation and maintenance phase, especially for the management of time, human resources, communication and procurement, as well as the application of technologies during the renovation phase. These results are somewhat surprising since the operation and maintenance phase extends over the longest period of the entire project's life cycle. Additionally, operational costs (e.g., energy consumption, maintenance management, waste treatment) are much higher than construction costs only (Santos et al., 2017; Wong et al., 2018a). A great deal of effort should therefore be placed into improvements in efficiency during the operation and maintenance phase. Nevertheless, building management and maintenance, which has been the subject of an appreciable number of papers covering maintenance processes and automatic processes to support building management, represents a key role in most recent studies in the Construction 4.0 literature (Santos et al., 2017). In particular, as shown in Appendix A, quality management, risk management and safety management during the operation and maintenance phase are receiving increasing attention from researchers.

\section{CONCLUSION}

This paper addressed research trends and needs associated with Construction 4.0. The analysis shows that most applied research aimed at integrating the concepts of Industry 4.0 into the specific context of construction project management has been focused on the pre-construction stage, dealing mostly with issues related to the design, engineering and construction phases. Most research on the design and engineering phase has dealt with the use of computer hardware and software to enhance the efficiency of project design and engineering, and developments in 4.0 technologies have mainly enabled design tasks to be computerized. During the construction phase, monitoring devices now allow companies to track construction processes and activities more rigorously and in real time. For example, 3D laser scanning is used to compare structures to the model and drones with cameras survey construction sites.

In addition, the survey shows that 4.0 technologies and concepts, such as monitoring systems, BIM, as well as tools that enable to locate human and material in space and/or time (e.g., RFID, GIS), have found their way into applications in the construction industry between 2009 and 2020. However, the applications of BIM, affecting organizational conditions and raising organizational challenges (Çidik et al., 2017; Papadonikolaki and Wamelink, 2017), still hold great potential for the future. For example, thoughtful use of BIM could help control construction quality by allowing timely discovery of potential problems through increased detail and information as of the design phase (Dallasega et al., 2018).

For the operation and maintenance phase, hardware technology (e.g., robots, sensors) has been mainly developed in recent years. Another promising direction to pursue is to further use the information generated in the operation and maintenance phase and to provide decision-support aiding tools for the management of that phase (Santos et al., 2017). To this end, systems integrating different informational technologies should be developed. However, given the differences between these technologies, they are usually utilized at separate practice fields. For 
example, GIS is commonly used at urban planning, transportation planning and urban design analysis, while BIM is often applied to architectural design and building construction management. Another direction worth pursuing thus involves the integration of different 4.0 technologies for the development of information systems. Integrating, for instance, information from GIS and BIM, as well as construction schedules and construction cost estimates could further advance the possibilities for sharing information among all stakeholders (CastroLacouture et al., 2017). The integration of different technologies may also address the challenge of construction progress monitoring through a correlation of collected progress data using different informational technologies. For example, BIM comprises useful design information, overused during the design phase but overlooked during construction. Schedule and cost information provided by BIM and compared with GIS-based as-built data may however provide decision makers with a useful tool for project monitoring with reliable progress indicators. The integrated digital building delivery system based on BIM and virtual reality technology proposed by Shuo (2013) and the GIS-BIM integrated model for the layout of tower cranes presented by Irizarry and Karan (2012) are two other good examples of technology integration.

Over the last decade, research in Construction 4.0 has also been limited primarily to the processes of quality management, risk management, and health and safety management. As the information model changes from providing management of shared building information in a standardized way (e.g., BIM alone), to allow an integrated model of information distributed in real time (e.g., BIM combined with other technologies) in order to take appropriate corrective actions, 4.0 technologies will continue to bring about a great number of changes in all other processes of construction project management, including time, human resources, communication and procurement. One interesting question in this line might be the potential improvement from the integration of 4.0 technologies for the purpose of re-engineering, automation and industrialization of actual project management processes. Indeed, even if construction companies now have several technologies to collect project data, through the use of drones, cameras, telemetry tools, sensors and RFID for instance, the data available via these technologies are unfortunately not the total answer and project data models have yet to be developed to improve current project management processes.

\section{ACKNOWLEDGEMENTS}

This work has been supported by the Pomerleau Industrial Research Chair in Innovation and Construction Project Governance and the Jarislowsky / SNC-Lavalin Research Chair in the Management of International Projects. Their support is gratefully acknowledged.

\section{REFERENCES}

Abolghasemzadeh, P. (2013). A comprehensive method for environmentally sensitive and behavioral microscopic egress analysis in case of fire in buildings, Safety Science, 59, 1-9.

Adán, A., Prado, T., Prieto, S.A. and Quintana, B. (2017). Fusion of thermal imagery and LiDAR data for generating TBIM models. In Proceedings of the 16th IEEE sensors conference, IEEE, 1-3.

Alves, M., Carreira, P. and Costa, A.A. (2017). BIMSL: A generic approach to the integration of building information models with real-time sensor data. Automation in Construction, 84, 304-314.

Araszkiewicz, K. (2017). Digital technologies in facility management - the state of practice and research challenges. Procedia Engineering, 196, 1034-1042.

Aripin, I. D. M., Zawawi, E. M. A. and Zulhabri, I. (2019). Factors influencing the implementation of technologies behind ndustry 4.0 in the Malaysian construction industry. In MATEC Web of Conferences, Vol. 266, EDP Sciences, 1-6.

Bolognesi C., Fiorillo F. and Aiello D. (2020). Three renaissance vaults in Milan. Cultural heritage and digital workflows for BIM modelling. In M. Di Nicolantonio, E. Rossi and T. Alexander (Eds), Proceedings of the AHFE 2019 international conference on additive manufacturing, modeling systems and $3 D$ prototyping, Vol. 975, Springer Verlag, 202-211.

Bouslah, B., Gharbi, A. and Pellerin, R. (2014). Joint economic production and quality control of unreliable batch manufacturing systems with rectifying inspection. International Journal of Production Research, 52(14), 4103-4117. 
Bouslah, B., Gharbi, A. and Pellerin, R. (2016a). Integrated production, maintenance and quality control of deteriorating production systems. Omega, 61, 110-126.

Bouslah, B., Gharbi, A. and Pellerin, R. (2016b). Joint economic design of production, continuous sampling inspection and preventive maintenance of a deteriorating production system. International Journal of Production Economics, 173, 184-198.

Bouslah, B., Gharbi, A. and Pellerin, R. (2018). Joint production, quality and maintenance control of a twomachine line subject to operation-dependent and quality-dependent failures. International Journal of Production Economics, 195, 210-226.

Burgess, G., Jones, M. and Muir, K. (2018). BIM in the UK house building industry: opportunities and barriers to adoption. University of Cambridge, Cambridge Centre for Housing \& Planning Research.

Castro-Lacouture, D., Quan, S.J. and Yang, P.P.-J. (2014). GIS-BIM Framework for integrating urban systems, waste stream and algal cultivation in residential construction. In Proceedings of the 31st international symposium on automation and robotics in construction and mining, Sydney: University of Technology, 576-583.

Cecchini, C. (2019). From data to 3D digital archive: a GIS-BIM spatial database for the historical centre of Pavia (Italy). Journal of Information Technology in Construction, 24(November), 459-471.

Cheng, J.C.P. and Ma, L.Y.H. (2013). A BIM-based system for demolition and renovation waste estimation and planning. Waste Management, 33(6), 1539-1551.

Chowdhury, T., Adafin, J. and Wilkinson, S. (2019). Review of digital technologies to improve productivity of New Zealand construction industry. Journal of Information Technology in Construction, 24, 569-58.

Çidik, M.S., Boyd, D. and Thurairajah, N. (2017). Ordering in disguise: digital integration in builtenvironment practices. Building Research \& Information, 45(6), 665-680.

Dallasega, P., Rauch, E. and Linder, C. (2018). Industry 4.0 as an enabler of proximity for construction supply chains: A systematic literature review. Computers in Industry, 99, 205-225.

Danjou, C., Bled, A., Cousin, N., Roland, T., Perrier, N., Bourgault, M. and Pellerin, R. (2020). Industry 4.0 in construction site logistics: a comparative analysis of research and practice. The Journal of Modern Project Management, 7(4).

De Groote, M. and Lefever, M. (2016). Driving transformational change in the construction value chain. Belgium: Buildings Performance Institute Europe.

Dubas, S. and Pasławski, J. (2017). The concept of improving communication in BIM during transfer to operation phase on the Polish market. Procedia Engineering, 208, 14-19.

Edirisinghe, R. (2019). Digital skin of the construction site: smart sensor technologies towards the future smart construction site, Engineering, Construction and Architectural Management, 26(2), 184-223.

Ehrbar, H. (2016). Building Information Modelling - A new tool for the successful implementation of major projects of German railways. Geomechanics and Tunnelling, 9(6), 659-673.

Gerbert, P., Castagnino, S., Rothballer, C., Renz, A. and Filitz, R. (2016). Digital in engineering and construction: The transformative power of building information modeling. The Boston Consulting Group, Inc.

Getuli, V., Ventura, S.M., Capone, P. and Ciribini, A.L.C. (2017). BIM-based code checking for construction health and safety. Procedia Engineering, 196, 454-461.

Gustavsson, T.K., Samuelson, O. and Wikforss, O. (2012). Organizing IT in construction: present state and future challenges in Sweden. Journal of Information Technology in Construction, 17, 520-534.

Hajji, A., Gharbi, A. and Pellerin, R. (2012). Joint production control and product quality decision making in a failure prone multiple-product manufacturing system. International Journal of Production Research, 50 (13), 3661-3672. 
Hilfert, T. and König, M. (2016). Low-cost virtual reality environment for engineering and construction. Visualization in Engineering, 4(2), 1-18.

Hjelseth, E. (2017). BIM understanding and activities. WIT Transactions on The Built Environment, 169, 3-14.

Hossain, MD A. and Nadeem, A. (2019). Towards digitizing the construction industry: state of the art of construction 4.0. In D. Ozevin, H. Ataei, M. Modares, A. Gurgun, S. Yazdani, S. and A. Singh (Eds), Proceedings of the 10th international structural engineering and construction conference, ISEC Press, 13-1-13-6.

Hu, Z.-Z., Tian, P.-L., Li, S.-W. and Zhang, J.-P. (2018). BIM-based integrated delivery technologies for intelligent MEP management in the operation and maintenance phase. Advances in Engineering Software, $115,1-16$.

Isikdag, U. (2015). BIM and IoT: A synopsis from GIS perspective. International Archives of the Photogrammetry, Remote Sensing and Spatial Information Sciences, 40(2W4), 33-38.

Isikdag, U., Zlatanova, S. and Underwood, J. (2012). An opportunity analysis on the future role of BIMs in urban data management. In S. Zlatanova, H. Ledoux, E. M. Fendel and M. Rumor (Eds.), Urban and Regional Data Management-UDMS Annual 2011. London: Taylor \& Francis, 25-36.

Irizarry, J. and Karan, E. P. (2012). Optimizing location of tower cranes on construction sites through GIS and BIM integration. Journal of Information Technology in Construction, 17, 351-366.

Jian, L. (2017). The application and analysis of BIM in the optimization of large-scale construction projects. Boletín Técnico, 55(6), 782-796.

Koscheyev, V. and Hakimov, A. (2019). Russian practice of using digital technologies in public procurement management in the construction industry. In IOP Conference Series: Materials Science and Engineering, Vol. 497, No. 1, Institute of Physics Publishing.

Laine, R. and Ikonen, J. (2011). A construction plan image service for smart phones. In Proceedings of the 12th international conference on computer systems and technologies, Vol. 578, ACM, 292-297.

Lee, X.S., Tsong, C.W. and Khamidi, M.F. (2016). 5D Building information modelling - A practicability review. In Proceedings of the 4th international building control conference, Vol. 66, EDP Sciences, 2-7.

Lim, Y.-W., Majid, H.A., Samah, A.A., Ahmad, M.H., Ossen, D.R., Harun, M.F. and Shahsavari, F. (2018). $\mathrm{BIM}$ and genetic algorithm optimisation for sustainable building envelope design. International Journal of Sustainable Development Planning, 13(1), 151-159.

Lin, J.J.-C., Yang, C.-E., Hung, W.-H. and Kang, S.-C. (2013). Accessibility evaluation system for site layout planning - a tractor trailer example. Visualization in Engineering, 1(12), 1-11.

Mascort-Albea, E.J., Jaramillo-Morilla, A., Romero-Hernández, R. and Hidalgo-Sánchez, F.M. (2020). BIMGIS interoperability applied to architectonic heritage: 2D and 3D digital models for the study of the ancient church of Santa Lucía in Seville (Spain) (2020). In Proceedings of the 4th international congress science and technology for the conservation of cultural heritage, CRC Press/Balkema, 31-35.

Megahed, N.A. (2015). Towards a theoritical framework for HBIM approach in historic preservation and management. International Journal of Architectural Research, 9(3), 130-147.

Melzner, J. (2019). BIM-based takt-time planning and takt control: requirements for digital construction process management. In Proceedings of the 36th international symposium on automation and robotics in construction, International Association for Automation and Robotics in Construction, 50-56.

Moeuf, A., Pellerin, R., Lamouri, S., Tamayo, S. and Barbaray, R. (2018). The industrial management of SMEs in the era of Industry 4.0. International Journal of Production Research, 56(3), 1118-1136.

Monizza, G.P., Benedetti, C. and Matt, D.T. (2018). Parametric and generative design techniques in massproduction environments as effective enablers of Industry 4.0 approaches in the building industry. Automation in Construction, 92, 270-285. 
Monizza, G.P., Matt, D.T. and Benedetti, C. (2016). Parametric and generative design techniques for digitalization in building industry: the case study of Glued-Laminated-Timber Industry. IOP Conference Series: Materials Science and Engineering, 157, 1-5.

Moum, A. (2010). Design team stories: Exploring interdisciplinary use of 3D object models in practice. Automation in Construction, 19(5), 554-569.

Njike, A., Pellerin, R. and Kenne, J. P. (2012). Simultaneous control of maintenance and production rates for a manufacturing system with defective products. Journal of Intelligent Manufacturing, 23(2), 323-332.

Oesterreich, T.D. and Teuteberg, F. (2016). Understanding the implications of digitisation and automation in the context of Industry 4.0: A triangulation approach and elements of a research agenda for the construction industry. Computers in Industry, 83, 121-139.

Oreni, D., Cuca, B. and Brumana, R. (2012). Three-dimensional virtual models for better comprehension of architectural heritage construction techniques and its maintenance over time. In M. Ioannides, D. Fritsch, J. Leissner, R. Davies, F. Remondino and R. Caffo (Eds.), Lecture notes in computer science: Vol. 7616. Progress in cultural heritage preservation. Berlin: Springer-Verlag, 533-542.

Papadonikolaki, E. and Wamelink, H. (2017). Inter- and intra-organizational conditions for supply chain integration with BIM. Building Research \& Information, 45(6), 649-664.

Pärn, E.A. and Edwards, D. (2017). Vision and advocacy of optoelectronic technology developments in the AECO sector. Built Environment Project and Asset Management, 7(3), 330-348.

Pellerin, R. and Perrier, N. (2018). A review of methods, techniques and tools for project planning and control. International Journal of Production Research, 57(7), 2160-2178.

Petri, I., Kubicki, S., Rezgui, Y., Guerriero, A. and Li, H. (2017). Optimizing energy efficiency in operating built environment assets through building information modeling - A case study. Energies, 10(8), 1-17.

Pini, K., Cataldi, G., Faini, G., Piantelli, E., Lunardi, G., Faccioli, N., Menegola, I. and Sattamino, P. (2019). Interoperability between BIM models and 4.0 approach: theoretical models and practical cases. In Proceedings of the WTC 2019 ITA-AITES World Tunnel Congress, CRC Press/Balkema, 2859-2869.

Pocobelli, D.P., Boehm, J., Bryan, P., Still, J. and Grau-Bove, J. (2018). BIM for heritage science: a review. Heritage Science, 6(30), 1-15.

Poloprutský, Z. (2019). Building information model as a possibility for digital reconstruction of the buildings of rural architecture. International archives of the photogrammetry, remote sensing and spatial information sciences, 42(5/W2), 53-57.

Project Management Institute. (2013). A guide to the project management body of knowledge (5th ed.). Newtown Square, Pennsylvania: Project Management Institute.

Qin, J., Liu, Y. and Grosvenor, R. (2016). A categorical framework of manufacturing for industry 4.0 and beyond. Procedia CIRP 52, 173-178.

Rocha, L.F., Tavares, P., Malaca, P., Costa, C., Silva, J. and Veiga, G. (2017). Beam for the steel fabrication industry robotic systems. In Proceedings of the 34th international symposium on automation and robotics in construction (pp. 639-646). International Association for Automation and Robotics in Construction.

Santos, R., Costa, A.A. and Grilo, A. (2017). Bibliometric analysis and review of Building Information Modelling literature published between 2005 and 2015. Automation in Construction, 80, 118-136.

Scott, J., Laing, R. and Hogg, G. (2013). Built heritage digitization: Opportunities afforded by emerging cloud based applications. In Proceedings of the IEEE 5th international conference on cloud computing technology and science, Vol. 2, Cloud Computing Association, 88-93.

Scully, T., Doboš, J., Sturm, T. and Jung, Y. (2015). 3drepo.io: Building the next generation Web3D repository with AngularJS and X3DOM. In Proceedings of the 20th international conference on 3D web technology, Association for Computing Machinery, 235-243.

Shen, X., Liu, K. and Tang, L.C.M. (2013). Cost estimation in building information model. In Proceedings of the 2013 international conference on construction and real estate management: Construction and operation in the context of sustainability, ASCE, 555-566. 
Shuo, W. (2013). Integrated digital building delivery system based on BIM and VR technology. Applied Mechanics and Materials, 380-384, 3193-3197.

Sidawi, B. (2012). Management problems of remote construction projects and potential IT solutions: the case of Kingdom of Saudi Arabia. Journal of Information Technology in Construction, 17, 103-120.

Son, H., Kim, C., Kim, H., Han, S.H. and Kim, M.K. (2010). Trend analysis of research and development on automation and robotics technology in the construction industry. KSCE Journal of Civil Engineering, 14(2), 131-139.

Steel, J., Drogemuller, R. and Toth, B. (2010). Model interoperability in building information modelling. Software and Systems Modeling, 11(1), 99-109.

Stransky, M. and Matejka, P. (2019). Digital quality management in construction industry within BIM projects. In Proceedings of the 18th international scientific conference engineering for rural development, Vol. 18, Latvia University of Life Sciences and Technologies, 1707-1718.

Tahmasebinia, F., M.E. Sepasgozar, S., Shirowzhan, S., Niemela, M., Tripp, A., Nagabhyrava, S., Mansuri, k.k.Z. and Alonso-Marroquin, F. (2020). Criteria development for sustainable construction manufacturing in construction industry 4.0: theoretical and laboratory investigations. Construction Innovation, Vol. ahead-of-print, No. ahead-of-print. https://doi.org/10.1108/CI-10-2019-0103.

Tetik, M., Peltokorpi, A., Seppänen, O. and Holmström, J. (2019). Direct digital construction: technology-based operations management practice for continuous improvement of construction industry performance. Automation in Construction, 107(November), 1-13.

Tezel, A. and Aziz, Z. (2017). From conventional to IT based visual management: a conceptual discussion for lean construction. Journal of Information Technology in Construction, 22, 220-246.

Underwood, J. and Isikdag, U. (2011). Emerging technologies for BIM 2.0. Construction Innovation, 11(3), 252258.

Vanhoucke, M. (2018). Planning projects with scarce resources: Yesterday, today and tomorrow's research challenges. Frontiers of Engineering Management, 5(2), 133-149.

Wang, D. (2013). Analysis and application of BIM technology in the project goal control. Advanced Materials Research, 671-674(3), 2978-2981.

Wang, X., Yung, P., Luo, H. and Truijens, M. (2014). An innovative method for project control in LNG project through 5D CAD: A case study. Automation in Construction, 45, 126-135.

Whyte, J.K. and Hartmann, T. (2017). How digitizing building information transforms the built environment. Building Research \& Information, 45(6), 591-595.

Wong, J.K.W., Ge, J. and He, S.X. (2018a). Digitisation in facilities management: A literature review and future research directions. Automation in Construction, 92, 312-326.

Wong, J., Wang, X., Li, H., Chan, G. and Li, H. (2018b). A review of cloud-based bim technology in the construction sector. Journal of Information Technology in Construction, 19, 281-291.

Woodhead, R., Stephenson, P. and Morrey, D. (2018). Digital construction: From point solutions to IoT ecosystem. Automation in Construction, 93, 35-46.

Yeniceli, S. and Ozcelik, M. (2015). Practical application of 3D visualization using geotechnical database: A case study Karsiyaka (Izmir) settlement area (Turkey). Journal of the Indian Society of Remote Sensing, 44(1), 129-134.

Zhang, H., Tang, R., Qiu, J. and Qiu, X. (2019). Design and implementation of GIS+BIM-based digital campus system. In Proceedings of the international conference on artificial intelligence and advanced manufacturing, IEEE, 329-335.

Zhao, Q., Ma, Z., Hei, X., Zhu, Y. and Niu, J. (2017). A 3-D structural components automatic modeling method based on BIM. In Proceedings of the 13th international conference on computational intelligence and security, IEEE, 59-63.

Živec, T. and Žibert, M. (2016). The 3D geological model of the Karavanke tunnel using Leapfrog Geo. In Proceedings of the ITA-AITES World Tunnel Congress 2016, Vol. 3, Part 3, Englewood, CO: Society for Mining, Metallurgy and Exploration, 1858-1867. 
APPENDIX A: Classification of technologies, their applications and associated actions.

\begin{tabular}{|c|c|c|c|c|}
\hline & Design and engineering & Construction & Operation and maintenance & Renovation \\
\hline 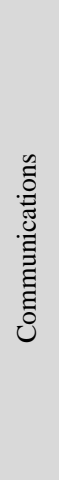 & $\begin{array}{l}\text { Visualize } \\
\text { - 3D visualization of digital models and texture } \\
(\mathrm{AR} / \mathrm{VR} / \mathrm{nD} \text { modeling })_{1} \\
\text { - 3D visualization of building information }(\mathrm{VR})_{2} \\
\text { Communicate } \\
\text { - Improvement of customer understanding in the } \\
\text { design phase }(\mathrm{VR})_{3} \\
\text { Standardize } \\
\text { - Communication standard } 2,3,4,5,6,7,8,9,10,11,12,13,14\end{array}$ & $\begin{array}{l}\text { Visualize } \\
\text {-3D visualization of digital models and texture (AR/VR/nD modeling) } 1 \\
\text { Communicate } \\
\text { - Reading (mobile devices) } 3 \\
\text { - Access to information (mobile devices) } 6 \\
\end{array}$ & & \\
\hline $\overrightarrow{0}$ & $\begin{array}{l}\text { Simulate } \\
\text { - Cost estimation according to the size of building } \\
\text { elements (nD modeling/drone/point cloud) } 15 \\
\text { - Estimation of future energy consumption } \\
\text { (WSN/advanced sensors) } 16 \\
\text { Optimize } \\
\text { - Heuristic methods for project planning (neural } \\
\text { networks/AI) } 17 \\
\text { - Facilitation of mass production (PD) } 18,19\end{array}$ & $\begin{array}{l}\text { Locate } \\
\text { - Waste location (drone) } 39 \\
\text { - Mapping of elements or groups of elements on site } \\
\text { (drone/UAV/photogrammetry) } 40 \\
\text { Automate } \\
\text { - Assembly automation (mobile robots on site) } 21 \\
\text { - Worker replacement (e.g., assembling bricks) (mobile robots on site) })_{21} \\
\text { - House construction (3D printing) } 41 \\
\text { Standardize } \\
\text { - Cost reduction (prefabrication) } 3\end{array}$ & \begin{tabular}{|l|} 
Locate \\
- Associated energy management (laser \\
scanning/infrared camera) 6
\end{tabular} & \\
\hline 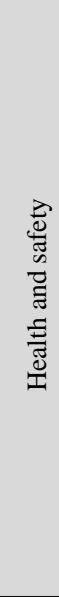 & $\begin{array}{l}\text { Model } \\
\text { - Modeling for safety and building exit means in case } \\
\text { of fire (WSN/mobile devices) }{ }_{20} \\
\text { Simulate } \\
\text { - Safety training (VR) })_{21} \\
\text { - Avoidance of crane collisions (GIS) })_{9,22}\end{array}$ & $\begin{array}{l}\text { Reconstruct } \\
\text { - Structure analysis (advanced sensors) } 1 \\
\text { - Safety inspection (drones) } 21,25 \\
\text { Locate } \\
\text { - Location and movement of workers and machines (productivity and safety) }{ }_{33} \\
\text { - Collision detection (RFID/Bluetooth/ultra sound) })_{30} \\
\text { - Avoidance of crane collisions (neural networks) } 9,22 \\
\text { - Worker safety (location // materials) (RFID/UHF) }{ }_{37} \\
\text { - Capture of hand movements (VR/camera) } 10 \\
\text { - Real-time data collection (mobile devices) } 29,40,42,43 \\
\text { - Wifi connections as a proxy for human occupancy (mobiles devices/WSN) } 9 \\
\text { Simulate }\end{array}$ & $\begin{array}{l}\text { Locate } \\
\text { - Locate occupants and fire sources in the } \\
\text { event of a fire (GPS) } 48 \\
\text { - Locate to facilitate emergency response } 49 \\
\text { - GPS-enabled tools for building fire safety } \\
\text { reviews } 48 \\
\text { Optimize } \\
\text { - Optimize the evacuation of occupants in } \\
\text { case of fire } 48 \\
\text { Communicate } \\
\text { - Safety, use of smartphone for guidance in } \\
\text { case of evacuation (mobile }\end{array}$ & \\
\hline
\end{tabular}




\begin{tabular}{|c|c|c|c|c|}
\hline & Design and engineering & Construction & Operation and maintenance & Renovation \\
\hline & & $\begin{array}{l}\text { - Data security for proof of delivery (blockchain })_{37} \\
\text { - Image analysis of the site to detect security problems (neural networks) } \\
\text { Communicate } \\
\text { - Safety training }(\mathrm{VR})_{21} \\
\text { Distribute } \\
\text { - Human control access on site (RFID) } 21 \\
\text { - Truck accessibility on site (RFID) } 26 \\
\text { - Improvement of material resource allocation on site (WSN/RFID) })_{24} \\
\text { Optimize } \\
\text { - Flow optimization (nD modeling/neural networks) } 22 \\
\text { - Optimization of crane location on site (neural networks) } 22\end{array}$ & \begin{tabular}{|l|} 
devices/smartphone) 48 \\
Automate \\
- Monitoring of structural deformations \\
(RFID)6
\end{tabular} & \\
\hline 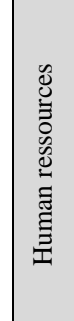 & $\begin{array}{l}\text { Simulate } \\
\text { - nD modeling }{ }_{1,2,6,8,10,15,20,23,24,25,26,27,28,29,30,31,32}\end{array}$ & $\begin{array}{l}\text { Locate } \\
\text { - Location of workers on site (GPS })_{25} \\
\text { - Detection of human movements (camera/webcam) }{ }_{10} \\
\text { - Location and movement of workers and machines (productivity and safety) })_{33} \\
\text { Distribute } \\
\text { - Human control access on site (RFID) })_{21}\end{array}$ & & \\
\hline 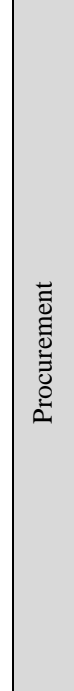 & $\begin{array}{l}\text { Simulate } \\
\text { - Avoidance of crane collisions (GIS)9,22 } \\
\text { Optimize } \\
\text { - Optimization of crane location on site (neura } \\
\text { networks) } 22\end{array}$ & $\begin{array}{l}\text { Locate } \\
\text { - Collision detection (RFID/Bluetooth/ultra sound) }{ }_{22} \\
\text { - Avoidance of crane collisions (GIS)9,22 } \\
\text { - Mapping of elements on site (mobile devices/nD modeling) }{ }_{40} \\
\text { - Tracking items in the supply chain (advanced sensors/RFID) } \\
\text { - Tag reading (mobiles devices/RFID) } \\
\text { Distribute } \\
\text { - Truck accessibility on site (RFID) }{ }_{26} \\
\text { - Improvement of material resource allocation on site (RFID) }{ }_{24} \\
\text { - Material and tracking control on site (RFID) } \\
\text { Optimize } \\
\text { - Flow optimization (nD modeling/neural networks) })_{22} \\
\text { - Optimization of crane location on site (neural networks) }{ }_{22} \\
\text { - Catalog purchases (neural networks) })_{44}\end{array}$ & & \\
\hline
\end{tabular}




\begin{tabular}{|c|c|c|c|c|}
\hline & Design and engineering & Construction & Operation and maintenance & Renovation \\
\hline & $\begin{array}{l}\text { Simulate } \\
\text { - Testing and verification of dynamic design solutions } \\
\text { (UAV/laser scanning) } 27,28 \\
\text { Standardize } \\
\text { - Program, programming } \\
\text { (IFC) } 2,3,4,5,6,7,8,9,10,11,12,13,14 \\
\text { - Standardization of design practices : rule validation } \\
\text { standard and standardization of product specificities } \\
\text { (PD) }\end{array}$ & $\begin{array}{l}\text { Model } \\
\text { - 3D modeling (drone) })_{21} \\
\text { - Digital quality management (3D BIM models) } 45,46 \\
\text { Automate } \\
\text { - Real-time progress of the construction site (drone/laser scanning) } 3 \\
\text { - Real-time data analysis (machine learning) } 42 \\
- \text { Measurement of production volume and calculation of productivity } \\
\text { (drone/laser) }{ }_{37} \\
\text { Optimize } \\
- \text { Heuristic methods for project planning (neural networks/AI) } 17 \\
- \text { Process efficiency improvement } 18 \\
- \text { Location and movement of workers and machines (productivity and safety) } 33 \\
\text { Standardize } \\
- \text { Delay reduction (prefabrication) } 18\end{array}$ & $\begin{array}{l}\text { Locate } \\
\text { - Monitoring the condition of building } \\
\text { elements (RFID/advanced sensors) } 43,48 \\
\text { - Building mapping to facilitate operations } \\
\text { and maintenance (drone/laser scanning) } 44 \\
\text { - Monitoring of structural deformations } \\
\text { (advanced sensors) } 6 \\
\text { yommunicate } \\
\text { - Follow-up of maintenance actions } \\
\text { (RFID) } 48 \\
\text { Automate } \\
\text { - Waste disposal (robots) } 21\end{array}$ & $\begin{array}{l}\text { Reconstruct } \\
\text { - Modeling of old buildings : geometry, texture } \\
\text { (point cloud/nD modeling) } 8,31,50 \\
\text { - 3D topography (drone/laser scan) } 34,35 \\
\text { - Thermal 3D point clouds (3D laser/RGB } \\
\text { camera/thermal camera) } 51 \\
\text { - Integration between 2D and 3D images (nD } \\
\text { modeling) } 48 \\
\text { - Two cameras to make a 3D point cloud } 48 \\
\text { - Modeling/Building reconstruction, point cloud, } \\
\text { historical building (laser scanning) } \\
\text { - Modeling accuracy and 3D model creation to } \\
\text { reconstruct an existing building (laser } \\
\text { scanning/photogrammetry/LiDAR) } 8 \\
\text { - Architectural heritage management (BIM-GIS) } 52,53 \\
\text { - Historic modeling (point cloud/laser scanner) } 54,55\end{array}$ \\
\hline$\frac{u}{a}$ & $\begin{array}{l}\text { Model } \\
\text { - Modeling for safety and building exit means in case } \\
\text { of fire (nD modeling) })_{20} \\
\text { Simulate } \\
\text { - Safety training (VR) } 21 \\
\text { Standardize } \\
\text { - Standard file, standard design, syntax standard, } \\
\text { visualization standard (IFC) })_{2,3,4,5,6,7,8,9,10,11,12,13,14}\end{array}$ & $\begin{array}{l}\text { Reconstruct } \\
\text { - Structure analysis (advanced sensors) } 1 \\
\text { - Safety inspection (drones) } 21,25 \\
\text { Locate } \\
\text { - Collision detection (RFID/Bluetooth/ultra sound) } 30 \\
\text { - Avoidance of crane collisions (GIS) }{ }_{9,22} \\
\text { - Worker safety (location // materials) (RFID/UHF) } 37 \\
\text { - Capture of hand movements (virtual reality/camera) })_{10} \\
\text { - Location and movement of workers and machines (productivity and safety) } 33 \\
\text { - Real-time data collection (mobile devices) } 29,40,42,43 \\
\text { - Wifi connections as a proxy for human occupancy (mobiles devices/WSN) } 9 \\
\text { Simulate } \\
\text { - Data security for proof of delivery (blockchain) } 37 \\
\text { - Image analysis of the site to detect security problems (neural networks) } \\
\text { Communicate } \\
\text { - Safety training (augmented reality) } 21\end{array}$ & $\begin{array}{l}\text { Locate } \\
\text { - Locate occupants and fire sources in the } \\
\text { event of a fire } 48 \\
\text { - Locate to facilitate emergency response } 49 \\
- \text { GPS-enabled tools for building fire safety } \\
\text { reviews } 48 \\
\text { Optimize } \\
\text { Optimize the evacuation of occupants in } \\
\text { case of fire } 48 \\
\text { Communicate } \\
\text { - Safety, use of smartphone for guidance in } \\
\text { case of evacuation } 48 \\
\text { Automate } \\
\text { Monitoring of structural deformations } \\
\text { (RFID) } 6\end{array}$ & \\
\hline
\end{tabular}




\begin{tabular}{|c|c|c|c|c|c|}
\hline & Design and engineering & \multicolumn{2}{|l|}{ Construction } & Operation and maintenance & Renovation \\
\hline 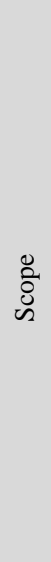 & $\begin{array}{l}\text { Locate } \\
\text { - Detection of drilling areas (laser) } 6 \\
\text { Reconstruct } \\
\text { - 3D topography (photogrammetry) }{ }_{33,34} \\
- \text { Field study (drone) } 35 \\
\text { Automate } \\
\text { - Automatic design of the building envelope according } \\
\text { to existing projects and constraints (PD) } 36 \\
\text { Simulate } \\
\text { - Smart contracts (blockchain) })_{37}\end{array}$ & $\mid$ & & $\begin{array}{l}\text { Automate } \\
\text { Reshape the building's functions and } \\
\text { layout by redesigning modules with } \\
\text { robotic cranes (crabots) }\end{array}$ & N/A \\
\hline$\underset{\Xi}{\Xi}$ & $\begin{array}{l}\text { Model } \\
\text { - nD modeling } 1,2,6,8,10,15,20,23,24,25,26,27,28,29,30,31,32,38 \\
\text { Visualize } \\
\text { - nD modeling } \\
\text { Simulate } \\
\text { - nD modeling } \\
\text { Optimize } \\
\text { - Heuristic methods for project planning (neural } \\
\text { networks/AI) } 17\end{array}$ & $\begin{array}{l}\text { Model } \\
\text { - 3D modeling (drone) })_{21} \\
\text { - } \mathrm{nD} \text { modeling (BIM) } 47 \\
\text { Automate } \\
\text { - Real-time progress of the construction site ( } \mathrm{d} 1 \\
\text { - Real-time data analysis (machine learning) } 42 \\
\text { Optimize } \\
\text { - Heuristic methods for project planning (neura } \\
\text { - Process efficiency improvement (PD) } 18 \\
\text { - Location and movement of workers and mach } \\
\text { Standardize } \\
\text { - Delay reduction (prefabrication) } 18\end{array}$ & (A) ${ }_{17}$ & & \\
\hline & $\begin{array}{l}\text { 1Oreni et al. (2012) } \\
\text { 2Shuo (2013) } \\
\text { 3Dallasega et al. (2018) } \\
\text { 4Hjelseth (2017) } \\
\text { 5Steel et al. (2010) } \\
\text { 6Santos et al. (2017) } \\
\text { 7Isikdag (2015) } \\
\text { 8Pocobelli et al. (2018) } \\
\text { 9Araszkiewicz (2017) } \\
\text { 10Hilfert and König (2016) } \\
\text { 11Rocha et al. (2017) } \\
\text { 12Alves et al. (2017) } \\
\text { 13Scully et al. (2015) } \\
\text { 14Shen et al. (2013) }\end{array}$ & $\begin{array}{l}\text { 15Lee et al. (2016) } \\
\text { 16Petri et al. (2017) } \\
\text { 17Zhao et al. (2017) } \\
\text { 18Monizza et al. (2018) } \\
\text { 19Monizza et al. (2016) } \\
\text { 20Abolghasemzadeh (2013) } \\
\text { 21Oesterreich and Teuteberg (2016) } \\
\text { 22Irizarry and Karan (2012) } \\
\text { 23Underwood and Isikdag (2011) } \\
\text { 24Wang (2013) } \\
\text { 25Tezel and Aziz (2017) } \\
\text { 26Lin et al. (2013) } \\
\text { 27 Getuli et al. (2017) } \\
\text { 28Moum (2010) }\end{array}$ & $\begin{array}{l}\text { 29Dubas and Pasławs } \\
\text { 30Ehrbar (2016) } \\
\text { 31Cheng et al. (2013) } \\
\text { 32 Jian (2017) } \\
\text { 33Pärn and Edwards } \\
\text { 34Y Yeniceli and Ozcel } \\
\text { 35Živec and Žibert (2 } \\
\text { 36Lim et al. (2018) } \\
\text { 37Woodhead et al. (2 } \\
\text { 38Zhang et al. (2019) } \\
\text { 39Castro-Lacouture e } \\
\text { 40Laine and Ikonen ( } \\
\text { 41 Tahmasebinia et al } \\
\text { 42 Whyte and Hartma }\end{array}$ & $\begin{array}{l}\text { ski (2017) } \\
\text { (2017) } \\
\text { lik (2015) } \\
2016) \\
2018) \\
\text { t al. (2014) } \\
(2011) \\
.(2020) \\
\text { inn (2017) }\end{array}$ & $\begin{array}{l}\text { t al. (2018) } \\
\text { cheyev and Hakimov (2019) } \\
\text { sky and Matejka (2019) } \\
\text { nker (2019) } \\
\text { et al. (2019) } \\
\text { g et al. (2018a) } \\
\text { lag et al. (2012) } \\
\text { t et al. (2013) } \\
\text { et al. (2017) } \\
\text { cort-Albea et al. (2020) } \\
\text { hini (2019) } \\
\text { gnesi et al. (2020) } \\
\text { prutský (2019) }\end{array}$ \\
\hline
\end{tabular}

